\title{
Susan Doran
}

\section{'The Late Raigne of Blessed Queene Elizabeth'}

\section{Memory and Commemoration of Elizabeth I in Early- Jacobean England}

This essay challenges the scholarship arguing that a politically inspired nostalgia for Elizabeth I existed throughout the reign of her successor, James I. Drawing the distinction, between memory and commemoration, Doran argues that personal recollections, public spaces, and book productions kept her memory alive between 1603 and 1613, the first decade of James's reign, but that commemorations of her were limited in scope until the Gunpowder Plot reimagined her role in England's antiCatholic narrative. Even then, the commemorations were not designed as a critique of James, until he was accused of betraying the Protestant cause during the 1620s.

The afterlife of Elizabeth I during the seventeenth century has been a popular subject of study. Yet few scholars, if any, have made a distinction between acts of memory and commemoration. Instead, they have fused the two concepts into a single act of remembrance which they usually call 'nostalgia'. Anne Barton, Daniel Woolf, and Curtis Perry were among the first to employ this nomenclature, when they explored Jacobean constructions of 'The Late Raigne of Blessed Queene Elizabeth' and discussed how the 'nostalgia' for Elizabeth could be used as a weapon to criticise her successor, James I. ${ }^{1}$ And 'nostalgia' has stuck. A recent book on the subject, falls back on the same word, its author Catherine Loomis seeking in 2010 to present 'a more complete picture of the sources of Jacobean nostalgia for the Queen'; ${ }^{2}$ while others have looked at how Jacobean playwrights, such as Thomas Dekker and Thomas Heywood, used 'the guise of nostalgia' to critique aspects of the king's policies. ${ }^{3}$ 
Despite the nuance of some of this scholarship, it is now time to ditch the notion of 'nostalgia. Leaving aside the fact that it is not a term that Jacobeans would have recognised since the word was not coined until the 1680s, 'nostalgia' implies a wistfulness and sentimentality which are mainly absent from Jacobean remembrances of the late queen. ${ }^{4}$ Furthermore, using a single concept like nostalgia homogenises the various ways that Elizabeth was remembered and consequently results in our misinterpreting certain aspects of the process and experience. And finally, early-modern historians have recently become more conceptual and sophisticated when discussing historical memory by distinguishing myth from memory, personal recollection from social memory, and what Philippe Nora has called 'sites of memory' [lieu de memoires] from 'real environments of memory' [milieu de memoires]. ${ }^{5}$

In this essay, I distinguish between the acts of remembering and commemorating Elizabeth I in the decade after James's accession in 1603. Commemoration of an individual, unlike an event, is usually eulogistic in tone and a deliberate attempt to reconstruct and reimagine the role of the departed. Remembering, albeit often spontaneous, can also be deliberately invoked for a particular purpose but without the intention to eulogise or myth-make. Admittedly the boundary between the two is sometimes blurred, but there is value in drawing a distinction. Certainly contemporaries, appreciated there was a difference, although the words they used tended to be 'remembrance' and 'memorial.' ${ }^{6}$ Moreover, my argument here is that remembrance of the late queen was widespread between 1603 and 1613, but that commemorations of her were limited in scope until the Gunpowder Plot of 1605 reimagined her role in England's anti-Catholic narrative and recreated the myth of Elizabeth as a providential monarch.

The remembrance of Elizabeth in early Jacobean England was inevitably strong among the political elite. Although men and women new to England filled the innermost sanctums of the court (James I's bedchamber and his wife's privy chamber), a substantial number of privy councillors, bishops, and lord lieutenants who were in situ from 1603 until 1612 had their own personal recollections of the late queen. Minor officials and members of the gentry may not always have had individual contact with Elizabeth, but they remembered her promises of bounty. The early Jacobean State and Cecil 
Papers are filled with letters and petitions informing James I and reminding Sir Robert Cecil of Elizabeth's promises of grants of land, reversions of offices, and privileges as yet unfulfilled. Additionally, Elizabethan office holders were keen to tell the new king of their past service to his predecessor in their pursuit of pensions or other rewards.

The cultural memory of the queen also lived on. First of all, her visual presence did not disappear. Although James immediately demanded a new coinage and ordered his own coat of arms to be set up in churches, old coins stamped with Elizabeth's head remained in circulation while her painted coats of arms were not quickly nor easily removed, especially as the work had to be done at the parish's expense. ${ }^{7}$ In many churches, moreover, elaborate tombs and memorials of prominent Elizabethans had been - and continued to be - erected with inscriptions referring, often at some length, to the deceased's relationship and service to the queen.

Nor did Elizabeth's portrait disappear from public spaces, even though on James's accession Venice's representative in London reported that they were being removed and hidden away. ${ }^{8}$ Not only did existing portraits continue to be hung in grand houses, town-halls, and educational establishments - especially those founded by the queen - but also new ones were commissioned as part of the sets of kings and queens which reached 'a peak of popularity' during the 1590s and early 1600s. ${ }^{9}$ Several new engravings of Elizabeth were likewise disseminated after her death, either as free-standing prints or part of a monarchical set. ${ }^{10}$

Illustrations of the queen appeared or reappeared in printed books after 1603, but not for commemorative purposes. To take a few examples, John Foxe's 1610 edition of the ever-popular Actes and Monuments retained the historiated $\mathrm{C}$ with her picture in the preface which had appeared in the earlier editions. ${ }^{11}$ Renald Elstrack's prints of Elizabeth enthroned and in parliament were two of the nine illustrations in Robert Glover's Nobilitas Politica vel Civilis. ${ }^{12}$ Similarly a whole-page drawing of the late queen with an accompanying verse appeared in Edward Grimeston's A Generall Historie of the Netherlands. At first glance, her representation in this latter work might seem a good example of Jacobean commemoration, but the context proves this was not the intention. The picture was just one of 57 such vignettes; nor did Elizabeth stand out because of her gender, for female regents and duchesses of the region were given the same space and their own lines of verse. While Grimeston's text, and the verse, compliment the queen as 'protectrix of their countrey', she is not presented as an iconic figure; there 
is no mention of her reviewing her troops at Tilbury, let alone delivering the now famous speech. ${ }^{13}$

Early Jacobean reprints of texts featuring Elizabeth were likewise not designed as acts of commemoration for the late queen. It was, for example, a sound marketing decision which led to the 1604 reprint (in two separate editions) of the description of her coronation passage from the Tower to Whitehall, just around the time when James I made his own royal entry into the City of London. ${ }^{14}$ The reprinting in 1608 of $A$ Booke of Christian Praiers containing Elizabeth's own compositions was a similarly a business decision, here based on the success of previous sales; the book had already been reprinted in 1578, 1581, and 1590. However, after 1604 there were no new editions, suggesting relatively poor sales and a loss of interest, not nostalgia, for the dead queen. ${ }^{15}$ Sermons that had previously been preached under Elizabeth were reprinted only when the subject matter was thought to have a new relevance under James. William Barlow's learned sermon of 1601 , reissued in 1609, began with greedy people ['eagles'] preying on the court and church for rich booty, a criticism which applied to both reigns, before moving on to discuss the nature of the 'body' in the sacrament. ${ }^{16}$

The first official act of commemorating Elizabeth came with her funeral. The procession from Whitehall to Westminster was a royal spectacle, costing over $£ 17,000$ and attracting a huge crowd; if literate, those who did not attend could read one of the many accounts of the spectacular parade. ${ }^{17}$ However, in comparison, the actual funeral service memorialising Elizabeth paled into insignificance. The sermon was neither printed nor circulated in manuscript in marked contrast to the funeral sermon on the death of James I which went into a second edition. If the Venetian envoy is to be believed, the sermon preached by Anthony Watson, Bishop of Chichester, praised the queen's successor as much as her: 'he declared how many blessings the land had enjoyed during hir raigne' and thanked God for 'electing' a king who would continue in like manner'. Nor was any other funeral sermon printed, even though Archbishop John Whitgift of Canterbury had asked one of Elizabeth's chaplains (Dr Parry) 'to make a kinde of funeral oracion ... to be published not pronounced.' ${ }^{18}$

Nonetheless, poets and printers capitalised on the sense of mourning for the dead queen to produce for sale hundreds of commendatory laments that 
eulogised her. In 1603 alone, there were nearly forty memorial pamphlets and verse collections published, not all of them sponsored by the government. ${ }^{19}$ Despite their differences, all the verses adopted the same language, tone, and themes which had been commonplace in the panegyric literature of the queen's lifetime. Praise centred on her unusual learning, facility with languages, piety, love of peace, and promotion of Protestantism. The epithets applied to her were just as recognisable. The dead queen was once again likened to biblical heroes (Moses, Samuel, David, Solomon, Josiah, Judith, Deborah, and Esther), pagan goddesses (Cynthia, Astraea, Pallas and Diana), and classical figures (Dido and Caesar). As in her lifetime, attention was paid to what was seen as the providential nature of her rule, the myth that God had protected her first as a princess and later as queen of England and had brought peace and prosperity to England during her reign in marked contrast to that of her half-sister Mary I. As in Elizabeth's last decades, much too was made of her virginity: Elizabeth was 'a unique virgin', a 'maiden queen', 'a royal maiden alone', a 'virgin sceptre swaying mother', even a 'divine virgin'. And, since her death occurred on the eve of the Annunciation, a few authors drew a comparison between her and the Virgin Mary. ${ }^{20}$

Yet, in every single elegy the dead queen had to share centre stage with her successor. The titles of many works say it all: Queene Elizabeths Losse, and King James his Welcome; Sorrowes Joy, Elizaes Memoriall, King James his Arriuall. And Romes Downefall; and Threno-thriambeuticon (meaning a composition both mournful and triumphant). In every tribute to the queen, the outpourings of grief at her death were followed by an outburst of joy at the accession of the new king. Even when titles referred only to grief at Elizabeth's passing, James I was joyfully hailed towards the end of the poem or song. The usual trope was that he was a second phoenix, rising from the queen's 'warme cynders', the phoenix, being a mythical bird that regenerated itself after it had been burnt to ashes as well as a motif employed by Elizabeth for much of her reign. Poets also favoured images that compared Elizabeth to the moon and James to the sun, or Elizabeth to winter and James to spring. ${ }^{21}$ This homage to James was to be expected. Authors were both following the conventions of the elegiac genre and more cynically seeking to ingratiate themselves with their new sovereign.

At the same time, there was in 1603 an alternative narrative to the eulogies in the commemorative elegies. The seventeen years of warfare, unfavourable economic conditions, and unpopular royal policies had created a perfect storm of political tensions, social unrest, and religious unease. Consequently, 
James was greeted with petitions, sermons, and speeches which amounted to a wholesale criticism of Elizabeth's rule. When he arrived at Stamford Hill, the London lawyer Richard Martin greeted him with an oration that briefly reminded the audience of Elizabeth's fame but went on to list the many evils in the commonwealth which she had left for her successor to redress: the neglect of the nobility, tax burdens on the commons, a depression of trade, corrupt lawyers, and the 'odious and unjust burden of monopolies'. Martin's speech was printed with the king's approval and thought important enough to be copied into several commonplace books. ${ }^{22}$

Martin was not alone. In three works printed in 1603, the Protestant minister Andrew Willets - developed the theme that the religious reformation advanced by Elizabeth remained to be completed by James, the Joshua to her Moses, the Solomon to her David. ${ }^{23}$ On the Catholic side, petitions told James of their 'hard times' under the old queen and pleaded for 'some benigne remedy and redresse of our most grievous calamities and afflictions. ${ }^{24}$ Although soliciting a new monarch to attend to longstanding public grievances was hardly novel, the wave of requests and complaints greeting James during his first regnal year was a blot on Elizabeth's memory, the very opposite of commemoration. ${ }^{25}$

Within four years of her death, Elizabeth appeared as a character in three plays, all of which might legitimately be viewed as commemorations of the dead queen. Thomas Heywood's 1604 play, If You Know Not Me, You Know Nobody with the sub-title The Troubles of Queene Elizabeth, contributed to the myth of Elizabeth by fictionalising John Foxe's account of the dangers which the pious and brave Protestant princess had faced during the Catholic Mary I's reign. Even though, in Heywood's 1605 sequel, The Second Part of Queen Elizabeth's Troubles, Elizabeth had a supporting rather than starring role, she appeared as an iconic figure, triumphant against England's Catholic foes, towards the end of the play. Hearing the Spanish Armada was on its way, she emerged 'compleately armed', declaiming:

... wee'le meet the worst can fall,

A mayden queene will be your generall. ${ }^{26}$ 
In Thomas Dekker's long allegorical play, The Whore of Babylon, first performed in 1606, Elizabeth was in the guise of Titania, the 'Faerie Queen', who in the last scenes was similarly depicted in full armour, mobilising forces against those of the empress of Babylon (explicitly standing for the Roman Catholic Church) and winning a great - if possibly only a temporary - naval victory over the empress. In the preface to the printed version of the play, Dekker declared that one of his purposes was to set forth 'the Greatnes, magnanimity, Constancy, Clemency and other the incomparable Heroical vertues of our late Queene., ${ }^{27}$

Yet these plays should not be interpreted as early Jacobean expressions of nostalgia for the dead queen and signs of disillusionment with her successor, as some scholars have claimed..$^{28}$ Almost certainly, commercial considerations not topical politics influenced their performance and printing. Heywood and Dekker were professional playwrights ready to exploit popular genres to make a living; and there had been several successful plays about recent history produced during the late Elizabethan and early Jacobean period. Heywood himself had already staged a pair of plays about Edward IV, while Dekker had co-written a drama about Sir Thomas $W y a t .^{29}$ The popularity of Heywood's Part 1, no doubt, tempted the playwright, stage producer, and a London printer to cash in on its success and introduce a Part $2 .{ }^{30}$ The Whore of Babylon was staged in the aftermath of the Gunpowder Plot and reflected anti-Catholic responses to that event. However, unlike Heywood's plays, it closed after just one performance, critics rightly seeing it as an incoherent pageant rather than an enthralling drama. ${ }^{31}$

In none of these works was there any obvious critique of James as part of a nostalgia for Elizabeth. On the contrary, Part 1 ends with her character uttering the hope that 'the happy yssue that shall us succeed' will 'build' his rule on the bible, a hope that might have seemed realised in 1605, for by then James had embarked on the task of putting together a team of scholars to create a new and better translation of the English Bible. Nor can this play be interpreted as an attack on James's recent peace with Spain, since Philip of Spain is portrayed as Elizabeth's protector. It was Mary and Stephen Gardiner, the bishop of Winchester, who are the evil geniuses of the drama. Heywood's sequel likewise does not seem to be a critique of the peace-loving James. Elizabeth is shown as a reluctant warrior, declaring in her last lines: 'We wish no warres, yet we must guard our owne', words that reflected James's own sentiment in his well-known work, Basilikon Doron. ${ }^{32}$ Besides, like its prequel, the play is anti-Catholic rather than anti-Spanish. 
A central strand of the drama was 'Dr Parrie's treasons' and the audience was invited to see the Armada as a strike at England by Roman Catholics rather than by Spanish imperialists. ${ }^{33}$ Likewise, in the preface to the text of The Whore of Babylon, Dekker declared a second purpose of the play was to reveal 'the inueterate malice, Treasons, Machinations, Vndermings, \& continual blody stratagems of that Purple whore of Rome. ${ }^{34}$ The names of characters in the play punned those of Catholics executed for treason in the 1580s: Doctor Paridel for William Parry; Campeius for Edmund Campion; and Lopus for Dr Lopez. What is more, in the third act, Dekker allowed a character (one of the empress's cardinals) to prophesy that:

A second phoenix rise, of larger wing,

Of stronger talent, of more dreadfull beake.

would drive away the birds taking shelter in the trees [denoting Catholic conspirators]. And, just in case readers of the play might miss the intended meaning, a marginal note in the script identified ' $\mathrm{K}$. James' as the 'phoenix. ${ }^{\text {'3 }}$

The continuing popularity of Heywood's plays can be explained by the fevered anti-Catholicism which followed the 1605 Powder Plot. Both his dramas reinforced the message that the Catholics' villainous treason was the culmination of their earlier attacks on England's Protestant monarch. Government propaganda during the winter of 1605-6 had made no attempt to present the Plot in this way, presumably because James had no wish to share the limelight with his predecessor. ${ }^{36}$ But the king had not been soft towards Catholics. The surviving conspirators had been executed, and harsh anti-Catholic legislation passed through the 1606 and 1610 Parliaments. Performances of Heywood's plays, therefore, did not represent critiques of government policy but rather reflected contemporary cultural attitudes.

The Powder Plot spawned a wide range of anti-Catholic material, whether sermons, poems, or polemic, recreating the same historical narrative which emphasised God's unswerving favour towards Protestant England and cast both Elizabeth and James as providential monarchs. In contrast to the elegies on her death, Elizabeth here sometimes overshadowed James. So, for example, in his 1607 sermon marking the anniversary of 5 November, John King (Elizabeth's one-time chaplain), lauded her as: 
a Queene of Queenes, a paragon (whilest she lived) of mortal princes, the diamond in the ring of the monarches of the earth, the glorie of hir sexe, the pleasure of mankind, the miracle of the Christian, and the mark and scope even of the infidel world...

All the preacher had to say about James was that his accession was equally the work of God. ${ }^{37}$

It was to commemorate the Plot and remember Catholic treachery that two painted panels were commissioned for display in St Faith's Church near Kings Lynn, Norfolk, one of them depicting Elizabeth reviewing the troops at Tilbury after the Armada's defeat, the other the Gunpowder plotters. The theme of the Tilbury panel was the sovereign's gratitude to God for delivering the nation from Catholic assaults, and at the top of the picture Elizabeth is shown at prayer declaring 'Blessed be the great God of my salvation'. At the bottom is placed a paraphrase of her speech to the troops.

James I realised he had much to gain by honouring Elizabeth's memory. Intelligent and canny as he was, the king deliberately chose to exploit the memory of his predecessor in order to legitimise his own authority and create a sense of continuity with the past. His main purpose was to reassure his new subjects that nothing significant had changed despite the fact that the king of a foreign country - a country that for many years had been England's enemy - was now sitting on the English throne. In this spirit, he consistently made positive references to the 'late Queene of famous memory' and 'Our late deere Sister Queene Elizabeth' in his parliamentary speeches and letters. Some of his proclamations, moreover, explicitly upheld, renewed, or extended provisions in orders and letters patent previously issued by Elizabeth. Commemoration was another matter. ${ }^{38}$ As shown in the siting of Elizabeth's tomb, James wanted to promote the Stuart dynasty and present his predecessor as a barren queen without progeny to continue her line. $39 \mathrm{He}$ and his consort Queen Anna drew on their success in procreation to present themselves as a young, fertile, and dynamic couple, a great improvement on the tired, decrepit, and barren queen who had recently passed away. 
In the same spirit James wanted England's national memory to centre on him rather than his predecessor. Two new holy days were introduced to mark his providential escape from death: Gowry Day on 5 August and the foiling of the Powder Plot on 5 November. The anniversaries of his accession (and, of course, Elizabeth's death) and coronation day were intended for jubilation. Bells were then rung in some parishes and cathedrals as they were on the king's birthday. By contrast there was no special national holiday or bellringing to commemorate either the defeat of the Spanish Armada nor Elizabeth's own accession day which had ended Catholic rule. ${ }^{40}$

James's approach to Elizabeth was generally successful during the first decade of his reign. Memory of her was usefully employed by the royal family; commemorations of her were generally muted. Furthermore, there is barely a hint that James's critics used her memory as a stick with which to beat the king. Given that he was censured for his favour towards the Scots, his desire for political union with Scotland, his personal extravagance, and his financial expedients, Elizabeth was not a useful standard of comparison, for her record on court corruption, favourites, and burdensome exactions was not held high. Protestant militants who disliked James's peace with Spain clustered around Prince Henry, who, they hoped, would emulate Sir Philip Sidney rather than the 'womanish' Queen Elizabeth.

All changed during the 1620s. By then the actual remembrance of Elizabeth had waned, not least because so many of those who had worked in her government or lived under her rule were dead. But the commemorations of the late queen flourished. In response to James's policies - his pursuit of a Catholic wife for his then heir, Prince Charles, and his failure to intervene on the Protestant side during the Thirty Years War - Elizabeth became politicised and mythologised as an oppositional figure in engravings and printed books. This was the period, too, when monuments to the dead queen proliferated in London's churches, while prints of her tomb in Westminster Abbey became popular. ${ }^{41}$ There was not much essentially new about the reconstructed Elizabeth, but the tone changed, for she was now used to shame the king and to spur him into a change of policy. The effect was to cast Elizabeth into a Protestant Amazon, the symbol of aggressive Protestantism and a role that suited her better in death than life. Once again, there was little in the way of nostalgia for a past age - rather, frustration and anger with the present one. 
Notes

1. Anne Barton, Harking Back to Elizabeth: Ben Jonson and Caroline Nostalgia', English Literary History 48 (1981), 706-73; Daniel R. Woolf, 'Two Elizabeths? James I and the Late Queen's Famous Memory', Canadian Journal of History 20 (1985), 167-91; Curtis Perry, The Making of Jacobean Culture (Cambridge: Cambridge University Press, 1997), 153-87. John Watkins also uses 'nostalgia', though argues that 'nostalgia for Elizabeth was not so widespread as scholars have believed, "'Old Bess in the Ruff: Remembering Elizabeth 1625-1660', English Literary Renaissance 30 (2000), 96.

2. Catherine Loomis, The Death of Queen Elizabeth I: Remembering and Reconstructing the Virgin Queen (Palgrave: Basingstoke, 2010), 4.

3. Sue Jones, 'English Bess' Abroad: Piracy, Politics, and Gender in the Plays of Thomas Heywood, Journal for Maritime Research 18 (2016), 87; James Knowles, “In the Purest Times of Peerless Queen Elizabeth”: Nostalgia, Politics, and Jonson's Use of the 1575 Kenilworth Entertainments', in Jayne Elisabeth Archer, Elizabeth Goldring, and Sarah Knight (eds), The Progresses, Pageants, and Entertainments of Queen Elizabeth I (Oxford: Oxford University Press, 2007), 247-67.

4. The word was coined in 1668 in a dissertation on the topic at the University of Basel by the scholar Johannes Hofer (1669-1752).

5. See, Judith Pollman, Memory in Early Modern Europe, 1500-1800 (Oxford: Oxford University Press, 2017); Alexandra Walsham, 'Chronicles, Memory and Autobiography in Reformation England', Memory Studies 11 (2018), 36-50, and 'History, Memory and the English Reformation', Historical Journal 55 (2012), 899-938; Philippe Nora, 'Between Memory and History: Les Lieux de Mémoires', Memory and CounterMemory 26 (1989), 7-24.

6. For example, Thomas Becon, The Flour of Godly Paiers (London, 1550); A Discourse or Traictise of Petur Martyr Vermilla (London, 1550).

7. 29 April 1603, National Archives, SP15/35 fol. $5^{\mathrm{v}}$. For the retention of Elizabeth I's coats of arms, see R.L. P. Jowitt, 'Displays of the Royal Arms in the Churches of Hampshire and the Isle of Wight', Papers \& Proceedings of the Hampshire Field Club \& Archaeological Society 18 (1954), 348, 352, 355, plate iv [334-5]. About a dozen coats of arms are extant.

8. Calendar State Papers, Venice, vol. 10, no. 22.

9. Catherine Daunt, 'Portrait Sets in Tudor and Jacobean England', Ph. D University of Sussex (2015), vol. 1, 125, 147, 167.

10. An individual print dated 1603 by Crispin de Passe; the set, Baziliologia, A Booke of Kings, being the true and lively effigies of all our English kings from the Conquest untill this present (London, first 1618).

11. John Foxe, Actes and Monuments of matters most speciall and memorable, happening in the Church, with an universall history of the same (London, 1610).

12. Robert Glover, Nobilitas Politica vel Civilis (London, 1608), facing 110, translated into The Catalogue of Honour or Tresury of True Nobility translated by Thomas Miles (London, 1610), 61, 69.

13. Edward Grimeston, A Generall Historie of the Netherlands (London, 1609), 890. 


\section{Doran}

14. Anon, The Royall Passage of her Maiesty from the Tower of Lon[don] to her Palace of White-hall (London, 1604).

15. STC, 6429, 6431, 6432, 6430, 7592 and 7593.

16. William Barlow, The Eagle and the Body Described in One Sermon Preached Before Queene Elizabeth of Precious Memorie, in Lent. Anno 1601 (London, 1609).

17. For cost, Folger Library, X.d. 541 fol. $1^{\mathrm{r}}$. For the printed texts describing the procession, W. A. Jackson, 'The Funeral Procession of Queen Elizabeth', The Library, 4th series, 26 (1945), 262-71.

18. Harold Spencer Scott (ed.), The Journal of Sir Roger Wilbraham (London: Camden 3rd Series, 1902), 169; Robert Parker Sorlien (ed.), The Diary of John Manningham of the Middle Temple 1602-3 (Hanover: University of Rhode Island, 1976), 244.

19. For a list of publications, see the Stuart Successions Project Website, database, stuarts. exeter.ac.uk.

20. Elizabeth Goldring et al (eds), John Nichols's The Progresses and Public Processions of Queen Elizabeth I: A New Edition of the Early Modern Sources (Oxford: Oxford University Press, 2014), vol. 4, 319, 342, 370, 654, 668, 672.

21. William Leighton, Vertue Triumphant (London, 1603), sig. A2 ${ }^{\mathrm{r}}$; Thomas Churchyard, Sorrowfull Verses Made on ... Death of Our Most Soueraigne Lady Queene Elizabeth, My Gracious Mistresse (London, 1604); John Lane, An Elegie Upon the Death of the High and Renowned Princesse, Our Late Soveraigne Elizabeth (London, 1603), sig. B3 ${ }^{\mathrm{v}}$; Henry Petowe, Elizabetha Quasi Vivens (London, 1603), B3 ${ }^{\mathrm{v}}$; Radford Mavericke, Three Treatises Religiously Handled: The Second Treatise (London, 1603), fol. $13^{\mathrm{r}}$ \& $^{\mathrm{v}}$; Anon, An Excellent New Ballad Shewing the Petigree of our Royall King James, the First of That Name in England (London 1603); Samuel Daniel, $A$ Panegyrike Congratulatorie (London, 1603), A2 ${ }^{\mathrm{r}}, \mathrm{A} 3^{\mathrm{r}}$. See also, Alan R. Young, 'The Phoenix Reborn: The Jacobean Appropriation of an Elizabethan Symbol', in Elizabeth Hageman and Katherine Conway (eds), Resurrecting Elizabeth I in SeventeenthCentury England (Madison, NJ, 2007), 68-81.

22. Richard Martin, A Speach Deliuered, to the King's Most Excellent Maiestie in the Name of the Sheriffes of London and Middlesex (London, 1603). Manuscript copes can be found in various places, including British Library, Egerton MS, 2877, fols 789; National Library of Scotland, 5831, fols $106^{\mathrm{r}}-115^{\mathrm{v}}$; Huntington Library, Ellesmere MS, 1224.

23. John N. King, 'James I and King David: Jacobean Iconography and its Legacy', in Daniel Fischlin and Mark Fortier (eds), Royal Subjects: Essays on the Writings of James VI and I (Detroit, 2002), 421-53.

24. NA SP14/1 fol. $110^{\mathrm{v}}$; BL, Additional MS, 39829, fol. 104.

25. Susan Doran, Regime Change: from Elizabeth I to James I, 1603-12, forthcoming.

26. Thomas Heywood, The Second Part of, If You Know Not Mee, You Know No Bodie (London, 1606), $\mathrm{K}^{\mathrm{r}}-\mathrm{K} 2^{\mathrm{v}}$.

27. Thomas Dekker, The Whore of Babylon (London, 1607), $A 2^{\mathrm{r}}$.

28. There is considerable literature on this. See for example, Perry, Making of Jacobean Culture,179-82; Woolf, 'Two Elizabeths?', 172-77. 
29. The First and Second Partes of King Edward the Fourth (London, 1599); Thomas Dekker and John Webster, The Famous History of Sir Thomas Wyat (played c.1602, printed 1607 reprinted 1612).

30. Its first title page called it The Second Part of, If You Know Not Mee, You Know No Bodie.

31. In his preface, 'Lectori', to The Whore of Babylon (London, 1607), Dekker blamed bad performances for the failure, but probably the drama's incoherence was equally if not more responsible, $\mathrm{A}^{\mathrm{v}}$.

32. Basilikon Doron, Or His Majesties Instructions to His Dearest Sonne, Henry the Prince (London, 1603), 60.

33. One subtitle of the play was 'Dr Parrie's Treasons'. For its attitude to Spain, David Womersley, Divinity and State (Oxford: Oxford University Press, 2010), 189.

34. Dekker, Whore, $\mathrm{A2}^{\mathrm{r}}$.

35. Dekker, Whore, $\mathrm{F} 2^{\mathrm{v}}$.

36. For example, His Majesties Speech in This Last Session of Parliament as Neere His Very Words as Could Be Gathered at the Instant....(London, 1605); William Barlow, The Sermon Preached at Paule's Crosse, the Tenth Day of November Being the Next Sunday after the Discoverie of This Late Horrible Treason (London, 1606).

37. John King, A Sermon Preached in Oxon: The 5. of November 1607 (Oxford, 1607), 22-3. See also, Robert Pricket, The Jesuits Miracles... (London 1607), E2 ${ }^{\mathrm{v}}-3^{\mathrm{r}}$.

38. Here I nuance Perry, Jacobean Culture, 155-7.

39. Peter Sherlock, 'The Monuments of Elizabeth Tudor and Mary Stuart: King James and the Manipulation of Memory', Journal of British Studies 46 (2007), 263-89.

40. Ronald Hutton, The Rise and Fall of Merry England: The Ritual Year 1400-1700 (Oxford: Oxford University Press,1994), 153-4.

41. Alexandra Walsham, in Susan Doran and Thomas S. Freeman (eds), The Myth of Elizabeth I (Basingstoke: Palgrave Macmillan, 2003), 157-63; Carole Levin, 'Elizabeth's Ghost: The Afterlife of the Queen in Stuart England', Royal Studies Journal 1 (2014), 1-16. 